\title{
Immunotherapy of genital warts with inosine pranobex (Imunovir): preliminary study
}

\author{
K C MOHANTY* AND C S SCOTT $\dagger$
}

\author{
From the *Department of Genitourinary Medicine, St Luke's Hospital, Bradford, and †Cookridge \\ Hospital, Leeds
}

SUMMARY One hundred and sixty five heterosexual men and women with genital warts were treated with inosine pranobex (Imunovir) or conventional treatment, or both. Inosine pranobex was found to be more effective in lesions of longer duration, whereas conventional treatment was more effective in genital warts of a shorter duration. Supplementation of conventional treatment with inosine pranobex increased the success rate from $41 \%$ to $94 \%$. Immunological studies in 134 patients with genital warts showed an increased number of B cells in $21 \%$ of peripheral blood samples. Absence of major defects among circulating lymphocytes suggested that patients with genital warts may have a local immune reaction.

\section{Introduction}

Various studies have shown a defective cell mediated immune system in patients with chronic warts. ${ }^{2}$ B cell activity in the form of IgG complement fixing antibody has been reported to be associated with regression of warts. ${ }^{34}$ The conventional treatment, which is available, is not universally satisfactory. Various alternative methods of treatment have been used to stimulate the immune system and produce a permanent cure. An antihelminthic, levamisole, was found to restore the cutaneous delayed hypersensitivity in anergic patients with cancer. ${ }^{5}$ In one study levamisole produced a cure rate of $90 \%$ in patients with common warts. ${ }^{6} \mathrm{~A}$ subsequent double blind study, however, showed that levamisole was no more effective than placebo. ${ }^{7}$ This drug has also become unpopular because of adverse reactions. ${ }^{8}$

Recently, a relatively safe immunomodulator, inosine pranobex (Imunovir, Edwin Burgess Limited), was introduced in the United Kingdom for the treatment of mucocutaneous herpes simplex virus infection. ${ }^{9}$ We decided to include inosine pranobex in a prospective study on the management of genital warts. The aims of the study were twofold: to study the immunology of patients with genital warts; to monitor

Address for reprinis: Dr K C Mohanty, Department of Genitourinary Medicine, St Luke's Hospital, Bradford, West Yorkshire, BD5 0NA

Accepted for publication 13 February 1986 the efficacy of conventional treatment, inosine pranobex alone, and conventional treatment supplemented by inosine pranobex.

This study was undertaken after approval had been given by the Committee on the Safety of Medicines, United Kingdom.

\section{Patients, materials, and methods}

The study, which was conducted at St Luke's Hospital, Bradford, and Airedale General Hospital, Steeton, included heterosexual men and non-pregnant women over 16 years of age, with at least three genital warts. All the men had warts on the glans, shaft, or coronal sulcus. None had intrameatal warts. Women had vulval or perianal warts, or both. Some of the women also had warts affecting the vagina and cervix. All patients were screened for various other sexually transmitted diseases. Those found to have other diseases, either on entry to the study or during follow up, were excluded from the analysis.

The study was performed in two parts. In the initial phase 65 patients were treated according to the routine procedures of the department (conventional treatment). Subsequently, following ethical approval, a further group of 145 patients were entered into a prospective randomised study, which compared the efficacy of conventional treatment, inosine pranobex, and conventional treatment supplemented with inosine pranobex. Patients in both parts of the study were similar as regards age, sex, and severity of disease. 
TREATMENT

Details of the treatment regimens were as follows:

Conventional treatment

Podophyllin $25 \%$ applied topically twice weekly for four weeks. If no response occurred patients received cryotherapy, or electrocautery if they had large warts.

\section{Inosine pranobex}

One gram three times daily by mouth for four weeks.

Conventional treatment plus inosine pranobex Podophyllin, cryotherapy, or electrocautery, plus $1 \mathrm{~g}$ inosine pranobex three times daily for four weeks.

\section{FOLLOW UP}

Patients were assessed at six and eight weeks and thereafter every four weeks, up to 24 weeks. Clinical cure was defined as the disappearance of the warts and the return of skin texture to normal. Relapse was defined as an initial clinical response but recurrence of the lesions during follow up. Cases that showed no improvement after six weeks were regarded as failures.

\section{HAEMATOLOGY TESTS}

Specimens of peripheral blood were taken for detailed immunological tests before treatment was started. Samples were not taken from those patients whose attendance at the clinic did not coincide with normal laboratory hours. Specimens taken from 21 healthy adult volunteers were used as controls.

Peripheral blood was collected into edetic acid anticoagulant for routine haematological investigations (Coulter S Plus 11), including absolute lymphocyte counts. Samples were also tested for B cells and $\mathrm{T}$ cell subpopulations, as described by Mills et al. ${ }^{10}$ The monoclonal antibodies used were Leu 12 (pan B cell determinant: Becton Dickinson), T11 (pan T, SRBC associated determinant: Coulter), OKT4 (helper $\mathrm{T}$ cell associated: Ortho), and OKT8 (suppressor T cell associated: Ortho). Ox erythrocytes coated with antibody were prepared by chromic chloride coupling ${ }^{10}$ and these "indicator" erythrocytes were used at a concentration of $1 \%$ in phosphate buffered saline. The observed percentages of CrCImonoclonal antibody rosette forming cells were corrected for non-lymphocyte (monocyte) contamination in the mononuclear fractions, and the absolute numbers of B, T, T helper, and T suppressor cells were calculated from the absolute peripheral blood lymphocyte counts.

\section{Results}

A total of 165 patients, 85 men and 80 women, completed the clinical study. Their mean age was $21 \cdot 2$ years. The number of patients who defaulted was similar in both parts of the study, and was mainly due to inadequate follow up. Table I shows the overall clinical response to the various treatments.

Of 36 patients treated with inosine pranobex, 14 (39\%) were cured, nine $(25 \%)$ relapsed, and there were $13(36 \%)$ treatment failures. The final rate of cure in the 91 receiving conventional treatment was 37 (41\%), with six (7\%) relapses and 48 (52\%) clinical failures. In this group podophyllin cured $19(32 \%)$ of 60 patients, and $17(59 \%)$ of the 29 patients who had cryotherapy were treated successfully. Electrocautery was used in only two patients; one was cured and the other relapsed. Statistical analysis showed that though cryotherapy or electrocautery, or both, was significantly more effective than podophyllin ( $p<0.5, x^{2}$ test), there were no differences between the responses obtained with inosine pranobex and podophyllin, cryotherapy, or electrocautery.

Further analysis of these two treatment groups indicated that inosine pranobex was more successful when used in patients whose warts had been present for a long time (mean duration 39.2 weeks), whereas conventional treatment was more effective with lesions of a shorter duration (mean $12 \cdot 6$ weeks) (table II).

When conventional treatment (primarily podophyllin) was supplemented by a course of inosine pranobex, the rate of cure was increased to $95 \%$ (36 of 38 patients). Relapse and failure were each recorded in one case.

Inosine pranobex was well tolerated. None of the

TABLE I Overall clinical response of 165 patients to various treatment regimens

\begin{tabular}{|c|c|c|c|c|c|c|c|c|c|}
\hline & \multicolumn{9}{|c|}{ No (\%) of patients receiving: } \\
\hline & \multicolumn{3}{|c|}{$\begin{array}{l}\text { Inosine pranobex } \\
\text { (17 men, } 19 \text { women) }\end{array}$} & \multicolumn{3}{|c|}{$\begin{array}{l}\text { Conventional treatment } \\
\text { (48 men, } 43 \text { women) }\end{array}$} & \multicolumn{3}{|c|}{$\begin{array}{l}\text { Conventional treatment plus } \\
\text { inosine pranobex ( } 20 \text { men, } 18 \text { women) }\end{array}$} \\
\hline & Cured & Relapsed & Failed & Cured & Relapsed & Failed & Cured & Relapsed & Failed \\
\hline $\begin{array}{l}\text { Men } \\
\text { Women } \\
\text { Total }\end{array}$ & $\begin{array}{r}7(41) \\
7(33) \\
14(39)\end{array}$ & $\begin{array}{l}4(24) \\
5(26) \\
9(25)\end{array}$ & $\begin{array}{r}6(35) \\
7(37) \\
13(36)\end{array}$ & $\begin{array}{l}17(35) \\
20(47) \\
37(41)\end{array}$ & $\begin{array}{l}4(8) \\
2(5) \\
6(7)\end{array}$ & $\begin{array}{l}27(57) \\
21(48) \\
48(52)\end{array}$ & $\begin{array}{l}18(90) \\
18(100) \\
36(95)\end{array}$ & $\begin{array}{l}1(5) \\
0(0) \\
1(3)\end{array}$ & $\begin{array}{l}1(5) \\
0(0) \\
1(3)\end{array}$ \\
\hline
\end{tabular}


TABLE II Correlation between response and duration of lesions

\begin{tabular}{lll}
\hline & \multicolumn{1}{c}{ Mean (SEM) duration of lesions in weeks } \\
\cline { 2 - 3 } Treatment & $\begin{array}{l}\text { Patients successfully } \\
\text { treated }\end{array}$ & $\begin{array}{l}\text { Patients unsuccessfully } \\
\text { treated }\end{array}$ \\
\hline Inosine pranobex & $39 \cdot 2(4 \cdot 4)$ & $13 \cdot 8(4 \cdot 1)$ \\
& $(\mathrm{n}=14)$ & $(\mathrm{n}=13)$ \\
Conventional & $12 \cdot 6(2 \cdot 4)$ & $31 \cdot 4(5 \cdot 5)$ \\
treatment* & $(\mathrm{n}=37)$ & $(\mathrm{n}=48)$ \\
\hline
\end{tabular}

* $\mathrm{p}<0.001$ Mann-Whitney U test; cures $v$ failures

patients reported side effects.

Tables III and IV show the immunological findings in 134 patients and 21 healthy volunteers. Of the 134 patients, 75 subsequently received conventional treatment, inosine pranobex was given to 26 , and 33 were in the combined treatment regimen group. Analysis of variance showed no significant difference between the three treatment groups in respect of the absolute numbers of lymphocytes, $\mathrm{T}$ cells, Leu- $12^{+} \mathrm{B}$ cells, OKT $-4^{+} \mathrm{T}$ helper, or OKT $-8^{+} \mathrm{T}$ suppressor cells. Similarly, no significant differences (Mann-Whitney rank sum test) were found between the male or female patient groups when compared with those of the normal controls. When the data for individual patients were analysed, however, various abnormalities were observed. An increased number of Leu-12+ B cells were recorded in $28(21 \%)$ patients; OKT $-4^{+}$T helper cells were reduced in seven $(5 \%)$ patients and increased in $12(9 \%)$. Increased OKT- $8^{+} \mathrm{T}$ suppressor cells were present in eight (6\%) patients.

\section{Discussion}

In this open study we found that inosine pranobex cured $39 \%$ of patients treated. This success rate does not differ significantly from that achieved with podophyllin or cryotherapy and does not justify the use of inosine pranobex alone for treating gential warts.

Overall, conventional treatment achieved a success rate of only $41 \%$. This was mainly due to the large number of patients given podophyllin. Podophyllin has already been reported as giving a poor response. ${ }^{11}$ In our hands cryotherapy cured $59 \%$ of patients, a similar success rate to that reported elsewhere. ${ }^{12}$

The observation that conventional treatment was particularly effective in patients whose warts had been diagnosed recently, whereas inosine pranobex proved more successful in lesions of longer duration, was interesting. The apparently lower efficacy of conventional treatment (primarily podophyllin) in warts of a longer duration may be a reflection of the previous failure of conventional treatment in some subjects. There is no such obvious explanation, however, for the differing responses to inosine pranobex in the two types of patients. It is tempting to speculate that the relative efficacy of conventional treatment and immunotherapy in the two categories of warts accounted for the higher clinical success rate of $94 \%$ achieved when the two modes of treatment were combined. This point warrants further study.

The immunological findings in patients with genital warts did not show any appreciable change in the number of OKT $-4^{+} \mathrm{T}$ helper and OKT $-8^{+}$ $T$ suppressor cells, or in the ratio of these $T$ cell subpopulations. The most common abnormality was

TABLE III Lymphocyte distributions in male and female patients with genital warts compared with those in normal healthy adult controls

\begin{tabular}{lllllll}
\hline & $\begin{array}{l}\text { Peripheral blood } \\
\text { lymphocyte count }\end{array}$ & $T$ cells & $B$ cells* & $T$ helper* & $T$ suppressor* & $\begin{array}{l}\text { Ratio of T helper: } \\
\text { suppressor cells }\end{array}$ \\
\hline Normal controls $(\mathrm{n}=21)$ & $2 \cdot 28(0.10)$ & $1.98(0.08)$ & $0.30(0.03)$ & $1.39(0.07)$ & $0.90(0.06)$ & $1.60(0.10)$ \\
Men $(\mathrm{n}=65)$ & $2 \cdot 71(0.13)$ & $2 \cdot 18(0.09)$ & $0.47(0.05)$ & $1.36(0.07)$ & $0.93(0.06)$ & $1.68(0.09)$ \\
Women $(\mathrm{n}=69)$ & $2.40(0.10)$ & $2.01(0.08)$ & $0.39(0.03)$ & $1.27(0.06)$ & $0.82(0.04)$ & $1.67(0.07)$ \\
\hline
\end{tabular}

*Results shown as absolute numbers $x 10^{9} / 1$ (mean values and standard errors).

T, B, T helper, and T suppressor cells defined by SRBC receptor, Leu -12, OKT-4, and OKT-8 monoclonal antibodies, respectively.

TABLE IV No (\%) of 134 patients with decreased or increased $T$ helper, $T$ suppressor, or $B$ cell* components and genital warts *

\begin{tabular}{|c|c|c|c|c|c|c|c|c|}
\hline \multicolumn{3}{|c|}{$\begin{array}{l}T \text { helper cells }\left(x \quad 10^{9} / l\right) \\
\text { (normal range } 0 \cdot 6-2 \cdot 1)\end{array}$} & \multicolumn{3}{|c|}{$\begin{array}{l}\text { T suppressor cells }\left(x 10^{9} / l\right) \\
\text { (normal range } 0 \cdot 3-1 \cdot 5)\end{array}$} & \multicolumn{3}{|c|}{$\begin{array}{l}B \text { cells }\left(\times 10^{9} / 1\right) \\
\text { (normal range } 01-06)\end{array}$} \\
\hline$<0.6$ & $2 \cdot 2-2 \cdot 7$ & $>2.9$ & $<0.3$ & $1 \cdot 6-2 \cdot 0$ & $>2 \cdot 0$ & $<0 \cdot 1$ & $06-1 \cdot 0$ & $>_{1} \cdot 0$ \\
\hline $7(5 \cdot 2)$ & $11(8 \cdot 2)$ & $1(0 \cdot 7)$ & & $7(5 \cdot 2)$ & $1(0 \cdot 7)$ & & $20(14 \cdot 9)$ & $8(6.0)$ \\
\hline
\end{tabular}

* T helper, T suppressor, and B cells defined by OKT4, OKT8, and Leu 12 monoclonal antibodies, respectively. 
an increased Leu- $12^{+}$B cell component. Absence of a major disturbance in peripheral blood lymphocytes does not rule out the possibility of local immune reactions in patients with genital warts. Two recent studies $^{13} 14$ support the concept that a local immunocompetent cell infiltrate is common in cervical human papillomavirus (HPV) infections. Interestingly, both we and Vayrynen et $a^{13}$ found that the number of $B$ lymphocytes was increased in peripheral blood (Leu-12 $2^{+}$) and cervical biopsy specimens (Leu$\left.10^{+}\right)$, respectively.

The natural history of genital warts is unpredictable, and a considerable number of patients will show spontaneous regression. Nevertheless, the results of this study and others reported elsewhere ${ }^{15} 16$ show a positive role for inosine pranobex in the management of such cases. Further trials, including double blind placebo controlled studies, are justified. It will also be valuable to monitor the effect of the drug on the local immune response of HPV lesions.

We thank Mr Paul Menday at Edwin Burgess Limited for providing the inosine pranobex tablets. We also thank all the nursing staff at the departments of genitourinary medicine, St Luke's Hospital, Bradford, and Airedale General Hospital, Steeton, for their cooperation. Finally, we thank Ms PM Lodge for typing the manuscript.

\section{References}

1. Mohanty KC, Roy RB. Thymus derived lymphocytes ( $\mathrm{T}$ cells) in patients with genital warts. British Journal of Venereal Diseases 1984;60:186-8.

2. Chretien JH, Esswein JG, Garagusi VF. Decreased T cell levels in patients with warts. Arch Dermatol 1978;114: 213-5.

3. Pyrhonen S, Penttinen $K$. Wart virus antibodies and the prognosis of wart disease. Lancet 1972;ii:1330-2.

4. Pyrhonen S, Johansson E. Regression of warts: an immunological study. Lancet 1975 ; i:592-5.

5. Tripodi D, Parks LC, Brugmans J. Drug induced restoration of cutaneous hypersensitivity in anergic patients with cancer. $N$ Engl J Med 1973;289:354-7.

6. Helin P, Bergh M. Levamisole for warts. N Engl J Med 1974;291:1311.

7. Schou $\mathbf{M}$, Helin P. Levamisole in a double blind study: no effects in warts. Acta Derm Venereol 1977;57:449-54.

8. Symoens J, Veys E, Mielants N, Pinals R. Adverse reactions to levamisole. Cancer Treat Rep 1978;62:1721-30.

9. Anonymous. Inosine pranobex and mucocutaneous herpes. Lancet [Editorial] 1985; ;:200-1.

10. Mills K, Armitage R, Worman C. An indirect rosette technique for the identification and preparation of human lymphocyte population by monoclonal antibodies. A comparison with immunofluorescent methods. Immunol Lett 1983;6:241-56.

11. Simmons PD. $10 \%$ and $25 \%$ Podophyllin in the treatment of ano-genital warts. A comparative double blind study. British Journal of Venereal Diseases 1981;57:208-9.

12. Simons PD, Langlet F, Thin RN. Cryotherapy versus electrocautery in the treatment of genital warts. British Journal of Venereal Diseases 1981;57:273-4.

13. Väyrynen M, Syrjänen K, Mäntyjärvi R, Castén O, Saarikoski S. Immunophenotypes of lymphocytes in prospectively followed up human papillomavirus of the cervix. Genitourin Med 1985;61:190-6.

14. Syrjäanen $\mathrm{KJ}$. Immunocompetent cells in uterine cervical lesions of human papillomavirus origin. Gynecol Obstet Invest 1983;16:327-40.

15. Malgouyat J. A new approach to the treatment of genital condyloma in the woman. Gynecologie 1983;34:415-7.

16. Sadoul G, Beuret TH. Treatment of cervical and vulvar condylomata by $\mathrm{CO}_{2}$ laser and an immunostimulant. Revue Francaise de Gynecologie et Obstetrique (Paris) 1984;79:6814. 